\title{
Exploring Writing Instruction in New Media Communication Context from the Perspectives of Multiliteracies Framework

\author{
Zhang Ying*
}

English Department, North China Electric Power University, Baoding, Hebei Province, China

\begin{tabular}{l|l}
\hline DOI: $10.36348 /$ jaep.2020.v04i07.002 & | Received: 28.06.2020 | Accepted: 06.07.2020 | Published: 08.07 .2020 \\
*Corresponding author: Zhang Ying &
\end{tabular}

\section{Abstract}

The study designs procedures of EFL writing instruction from the perspective of multiliteracies framework. It provides details of the application of four phases of mulitiliteracies approach. Findings from the follow-up interview showed students' positive attitude towards this new model of instruction. They demonstrated an active engagement in the learning process and became more responsible for the cooperative multimodal composing task. The multiliteracies approach provides students with experiences of constructing meanings via multiple semiotic resources, which is rewarding for enhancing their multiliteracies competence in authentic communications.

Keywords: multiliteracies, learning design, writing instruction.

Copyright @ 2020: This is an open-access article distributed under the terms of the Creative Commons Attribution license which permits unrestricted use, distribution, and reproduction in any medium for non-commercial use (NonCommercial, or CC-BY-NC) provided the original author and sources are credited.

\section{INTRODUCTION}

The development of web-based communication through new media expands the concept of writing. The integration of digital literacies in communication enables people to access complicated information through visual and aural images at a deeper level to a larger extent. Thus, the multiple forms of meaning-making have changed the way we compose texts and the context we negotiate meanings with audience. Cope and Kalantzis [2] define four scales of new media communication: agency, divergence, multimodality and conceptualization. Both writers and audience are producers of information as well as consumers of a variety of communication venues in the era of new media. Further, it allows writers with diverse social, cultural and linguistic backgrounds to exchange ideas freely in the globalized world. Another important aspect of new media communication is its multimodal resources used for delivering meanings for writers to develop more sophisticated thoughts. Besides, conceptualization in the communication of new situations requires composers of multimodal texts to be critical and reflective.

The shift to the new media communication calls for a large-scale change in writing instruction for learners growing up in such a multimedia world who need to learn how to communicate appropriately and effectively through multiple modes. According to Anstey and Bull [2], a multiliterate person should be "flexible and strategic and can understand and use literacy and literate practices with a range of texts and technologies; in socially responsible ways; in a socially, culturally, and linguistically diverse world; and to fully participate in life as an active and informed citizen" (p.55). Thus, new technologies and digital media should be integrated into writing instruction to meet learners' needs. The technologies and media employed in teaching writing are more than simple instrumental tools to draw students' attention. Instead, it should be able to scaffold students' development of multiliteracies and promote students' communicative competence in the increasingly multimodal context. However, $\mathrm{Li}$ and Feng [3] found that despite the multiple resources and modes used as teaching materials, the teacher-centered instruction still plays a fundamental role in class and less attention is paid to cultivating students' abilities of flexible application and independent analysis. While students press for gaining helpful support in participating more seamlessly in interactions within the web-based world. Therefore, this study is to explore how to facilitate EFL students' development of communicative competence in new media situations through writing instruction based multiliteracies framework.

\section{Understanding Multiliteracies in Language Instruction}

To address the increasingly multimodal and multimedia needs in classroom practice, the New 
London Group [4] proposed a multiliteracies pedagogy to explore how to change the traditional teaching and learning methods to make effective use of multimedia resources and cultivate students' abilities of multiliteracies in the $21^{\text {st }}$ century. This new pedagogy advocates "learning by design", highlighting three continual stages in the instructional process: available design, designing, and redesign. Available design is the existing resource represented by the acquired semiotic rules and theories; design refers to the process of using multiple semiotic resources to make meanings; redesign means the resources generated by the design process can become new resources with the potential to be activated in the next round. From the perspective of teachers, the New London Group [6] further put forward an instructional model including four elements: 1) situated practice: teachers create an authentic context to conduct the instruction that students are guided to participate in their familiar and experienced activities connected with the current new learning objective. This is in accordance with the core principle of Constructivism that learners actively build up new knowledge on the basis of their personal experiences and prior knowledge; 2) overt instruction: teachers use metalanguage in explicitly interpreting important concepts in semantics to guide students to construct meanings in real communicative contexts through the use of various modes; 3) critical framing: teachers cultivate students' abilities of critical analysis and provide the scaffold to help them develop social awareness of language use in communication and conceptualize important theories and principles in evaluation; 4) transformed practice: teachers foster students' application abilities through encouraging them to practice using multiple modes to construct meanings to solve practical problems in new situations.

Consistent with the above four elements in multiliteracies instruction, four procedures included in students' learning process are defined by Kalantzis and Cope [5], namely, experiencing, conceptualizing, analyzing and applying. Experiencing refers to bringing personal experiences and existing knowledge to the present learning situations to observe and participate in the new or unfamiliar learning tasks. Conceptualizing refers to classifying and grouping the learned things to form ideas stored in our brain. Analyzing is further divided into two processes, the process of functional analysis and of critical analysis. And applying is first to test the appropriateness of use of semiotic modes to convey meanings in familiar contexts, and it also means using these modes to achieve communicative purposes in new situations creatively.

The multiliteracies pedagogy is crucial in directing the interactions between teachers and students in writing instruction of new contexts as well as enlightening for designing teaching and learning activities in class. Studies exploring the integration of multiliteracies approach in writing instruction are rather limited [6]. In China, many studies on multiliteracies instruction focus on the teaching effect, while the design and the process of the application of multiliteracy pedagogy are not discussed fully. The difficulty is that whether the instruction only used multimodal resources in isolation or integrated multiliteracies teaching methods is not evident [7]. Only a few research explained the instructional process based on the theory of learning by design in detail $[8,7$, $9,10]$, but scarce attention has been given to the writing classroom. Therefore, the current article aims to provide insights into the design of writing instruction based on multiliteracies pedagogy.

\section{Writing Curriculum Design Based on Multiliteracies Framework}

Expository writing is a compulsory course for freshmen of English majors scheduled in the second semester. The general objective of the course is to gradually improve students' abilities to think and write in English. According to class observation and former students' comments on the course, the course content was perceived as dull and irrelevant to students' experiences, and students did not actively participate in writing tasks. Besides, the course was still conducted in a model of traditional teacher-centered literary education. The researcher of this study tries to reform the writing instruction design for the course based on multiliteracies pedagogy. The new model of writing instruction is constructed from four procedures: situated practice, overt instruction, critical framing and transformed practice. In the following, the unit of process writing of the course is used as an example to illustrate the detailed design of the teaching and learning process.

\section{Situated Practice}

Before class, teachers should provide students with rich opportunities to access the topic through multimedia resources. Teachers send relevant text, audio, video and graphics to students for discussion and synthesis. This step helps students to relate daily life communications within sociocultural contexts to language practice in classroom.

The instruction focus of this unit is on how to write process analysis essay. First, before class, the teacher sent students several videos from authentic communication contexts as supplementary materials, such as how to cook British breakfast, how to give first aids, how to post ads online, how an engine propels a jet, how a cell phone takes pictures, etc.. The scripts of these video programs are also offered to students. Then, students were assigned to form small groups for further discussions. Several post-watching questions were listed for discussion. For example, what are the similarities and differences among these videos? What are the purposes of these video programs? Who are the potential audience? What are the styles or features of the language used in videos, and why? How does the 
speaker make the process logic and clear for audience? After discussion, students had to make preparations to report their findings through PPT presentations in class. In presenting their findings explicitly, multiple modes of evidence related to their analysis should be given, such as textual, visual and aural information. Participating in these activities can encourage students to interact and cooperate with their classmates in choosing from a variety of modes to negotiate meanings with their audience appropriately. The familiar contexts enable students to activate their former personal experiences to construct associations with the present learning context. Thus, students have a strong desire to bridge the gap between what they know outside of the classroom and what they will do inside of the classroom. In addition, the multiple mode resources obtained at this stage also purposefully prepare students for their learning activities at the next stage.

\section{Overt Instruction}

During class, teachers are facilitators to help students analyze and summarize the characteristics, the target audience and communicative purposes of the videos and provide explicit guidance to students in constructing their knowledge system. Additionally, teachers at this stage need to cultivate students' abilities in selecting alternative multimodal resources to deliver meanings.

At the beginning of the class, representative students of each small group gave oral presentations of their discussion assignment through PPT which includes information of text, image, video, and graphics. Based on students' performance on the presentation, the teacher provided instruction about the principles of process analysis writing to students. Through in-class interactions, students came to find out the features of two types of process analysis: directional analysis and informational analysis in real communications. Also, students were guided to understand that to obtain the communicative purposes respectively, composers of the videos employed different strategies to elaborate on each step of the process, for example, adding time signals, explaining the purpose, defining unfamiliar terms, warning the audience what not to do, anticipating possible difficulties or problems. All of these were conveyed through pictorial as well as verbal information to deliver a clear message to the audience. From the perspective of language use and rhetorical device, students summerized that present tense and imperative sentences were used most frequently in videos, which served for the communicative purposes of this type of discourse. Teacher's overt instruction in class offers a up-down direction for students to approach the topic and distinguish it from other similar concepts. The next step was to provide students with more opportunities to gain a deeper and wider entry through co-constructing their knowledge together with the teacher in teacherstudents and students-students interactions. The teacher played a recording of an interview about preparations before boarding a plane and gave students some pictures to show the procedure step by step. Students were required to write down each step in English and explain each step in an informative way with discussed strategies in the former task. The assignment for this class was to cooperate with their group members to produce a video about how to board a plane and bring their products to the next class and share with their classmates. Students had one week to prepare and complete their assignment. Students were encouraged to research, design and apply new media or multiple modes to convey meanings to their audience effectively. After-class workshops were organized for students to get guidance and instruction about using technical tools in recording and editing videos, such as Movie Maker, AVS Video Editor. Students were also required to prepare the script of their videos, and write a reflective journal about the process of fulfilling the task with their group members.

\section{Critical Framing}

This stage took place in the second period of this unit when representative students of each small group presented and shared their video products with classmates. Through presentation, students demonstrated their multiliterate communicative competence, thus obtained a sense of fulfillment and improved their confidence in using multiple modes to create meanings. Through peer review and the teacher's feedback on their multimodal work, students were supported with opportunities to learn from each other and cooperate with peers, which helped to raise their sociocultural awareness in communication and cultivate their critical abilities of thinking and analyzing in multiliteracies.

Two fundamental components, functional analysis and critical analysis, account for the process of critical framing [5]. For this writing curriculum, based on Halliday's [11] theory of metafunction that language is used for representing ideational, interpersonal, and textual meanings in communication, the part of functional analysis of students' work includes three aspects: the written text (script), the interactions between composers and audience, and the employment of multiple modes or digital semiotic resources to achieve the communicative purpose. In the assignment, the purpose of the video is to provide audience with concrete directions for boarding an airplane. The composers of video are providers of information about the procedures who play a dominant role, and the audience are information seekers to get instructions from the composers in the communication. Therefore, the interactions in the video functions as a kind of commands from the experienced "expert" to the inexperienced viewers. This particular function of language use determines students' selection of semiotic resources to reach their desired effects. For example, one group used an animation about how to go through 
security check to warn the audience to remove certain items (such as electronic devices, liquids and gels) from their handbags for screening. Another group integrated into their work an image of a digital running clock and background music. The clock functioned as time signals to connect and arrange different steps; the music served as a helpful device to evoke audience' emotions and involve them in the content of their video program. Another group edited special soundtrack to draw the attention of audience to some possible difficulties and anticipated problems in the step of getting to the airport in time. For the part of critical analysis, a rubric consists of the elements of content, organization and language use was given to students as guidance for peer review of the script. For both of the two parts of analysis, students worked as groups to evaluate their classmates' work. Each group needed to accomplish their evaluation on two pieces of work from other groups. They had to write down overall comments and suggestions for improvement. Then, further discussions among groups were beneficial for students in later revision of their programs.

\section{Transformed Practice}

According to the development of learner's application abilities, transformed practice can be further divided into two stages: application to test the appropriateness of multiliteracies use in familiar situations and application to solve problems creatively in new contexts [5]. In the present writing curriculum, the instructional objective of this procedure is to foster the development of students' abilities to analyze practical problems independently and to construct meanings appropriately and innovatively by using multiliteracies skills and multiple semiotic resources in new media communication.

Both in-class activities and out-of-class tasks were conducted to obtain the instructional goal. Before class, based on the former peer review and the feedback offered by the teacher, students revised their video programs of boarding a plane and got their products published online through blogs and Wechat. Then, in class, students were assigned into different groups to cooperate with others to discuss the designing of a multimedia program on the following topics, for example, how to make a good video; how to open a bank account; how to prepare for a job interview; how to cultivate a hobby. Their discussions should include the design of content (analysis of the target process) and the integration of multiple semiotic modes in conveying meanings. Oral presentations of the group's design were delivered in class later, and interactions between speakers and audience were encouraged. Another part of practice in this unit was conducted through afterclass assignment. Students were asked to to carry out an interview among freshmen to find out the problems and difficulties they may encounter in lives or academic studies during the first year in the university. For example, some freshmen may feel lost in managing their time; some may have difficulties in selecting courses online; some are eager to know how to gain success in college. Students were required to do research on one of the topics in the interview that they found interesting. Then, they needed to complete a multimodal program to analyze the processes in solving the problem and share it openly through internet. The after-class task was to enable students to gain more experiences of applying what they had already known (the content knowledge and the multiple semiotic resources) to create meanings effectively in new situations, which was conducive for the improvement of their multiliteracies competence.

\section{Students' Perceptions towards Writing Instruction Based on Multiliteracies Framework}

After the session of writing instruction in this unit, a semi-structured interview was conducted to explore students' attitudes and feelings towards their engagement in multiliteracies tasks in the learning process. Four students in the class were selected randomly to participate in the interview. The students were voluntary and were informed of the purpose of the interview. The interview was carried out in participants' native language of Chinese, and all the data were transcribed later by the researcher of the present study. Four open-ended questions were designed to elicit participants' responses:

1) How do you feel about this writing class? Anything different from your past experiences?

2) How do you think of group work of making videos?

3) What does it feel like to share your composing product online?

4) What are your problems or difficulties in accomplishing the tasks of multiple modes?

For the first question, participants held a generally positive attitude towards the new model of writing instruction and preferred to use it in the following writing class.

This unit is quite different from former classes. The topic is coming from our daily life which is familiar to me and more interesting. I like it. (Student 1)

...I prefer to use this new style in the following classes. (Student 2)

Writing is a big headache for me because I always have nothing to say. But this time writing seems not so boring. ... I've learned how to compose an essay through different resources. It is more interesting and useful. (Student 3)

I think it is good... My group chose me to do the oral presentation, so I rehearsed several times and made lots of preparations. ... My performance was not bad and I became more confident in myself. (Student 4) 
Participants' reflections on the writing instruction indicate that authentic tasks in the real world can help bridge the gap between learners' personal experiences outside of the classroom and their learning activities inside. Thus, the familiar communicative situation becomes more interesting and meaningful for students who would like to spend more time and efforts in solving practical problems. In addition, through active participation and practice, students had more opportunities to experience success in class, leading to their higher level of self-efficacy as language learners. All of these factors may contribute to students' improved motivation in writing.

When asked their experience of making videos and publishing them online, the participants demonstrated a great passion.

This is the first time I have made a digital video and shared it openly through Internet. It was not an easy task. I and my group members spent a lot of time searching for the online pictorial and visual resources and editing the video. (Student 1)

Everyone needs to make efforts to contribute something to the program. ... I've learned a lot from other students. This will be helpful for me in future. (Student 2)

We had to sort out the most useful resources. We also discussed how to present information effectively to the audience, for example, through still images or animation, through special sound effect? This is a rewarding process. (Student 3)

I am exited to share my work with real audience. Before publishing our video, we discussed the needs of audience and revised and re-revised our video several time to make it perfect. (Student 4)

Participants' comments show that they actively participated in multiliteracy tasks and had a strong desire to publish their videos online to address a larger audience. The shift of roles from receptive information consumers to productive information providers is beneficial for the development of students' autonomous learning abilities and their sociocultural communicative competence. First, the task-based program in real world effectively engages them in searching for, classifying and evaluating the online information and multiple semiotic resources, which stimulates them to take more control over their learning process and learn autonomously. This is in line with Hafner \& Miller's [12] findings that communications with real audience in tasks can enhance learners' autonomy. Besides, the online communication between composers and extended audience also helps students to cultivate their social awareness in language use in reality. Another contributing element is students' cooperation with each other in group work. It creates opportunities for learners to learn from peers, and each individual has to shoulder his part of responsibilities that are accountable for completing the whole task.

In discussing the challenges and problems in doing multiliteracies tasks, participants reported their difficulties in sorting out multimedia information and lack of experiences in composing multimodal information through digital tools.

It is not easy to remix all the voices and images in the video. I have not done it before. (Student 2)

It took a lot of time to gather and screen multimodal resources. We also argued about the way of integrating this digital information into our video. (Student 3)

We were confronted with some technical problems, for example, adding subtitles, editing the video. So we tried to search out solutions through Baidu, and also asked other students for help. (Student 4)

It suggests that technologically-driven multimedia environment is changing the requirements for students' capacities to understand and create meanings. As claimed by Burn \& Parker [13], a multimodal composition requires learners to learn a new language about how to decode, interpret and produce information from juxtaposition of multiple modes. Therefore, it is a must for students to increase their awareness to constantly update their learning strategies and adapt to the new learning context. The technical problems should not hinder students from conveying meanings in this multimodal world. It is rewarding for students to access the remix information of text, image, sound, video more frequently in their learning process and develop their digital literacies, such as effectively using search engines, participating in web interactive platforms, script writing, to become more technologically sophisticated. The implication for teachers is that various semiotic resources should be integrated into their instruction to bridge the digital gap, and the practice of applying multimodal resources to constructing meanings should be an indispensable part of class activities. Another mission for teachers is to gradually enhance students' abilities of critical thinking. Teachers should guide students to carefully examine and screen the mass multimedia resources, to effectively build up the connection between modes of information and functions of meanings, and to sensibly make choices to fulfill particular communicative purposes.

\section{CONCLUSION}

The current study explored to construct an instructional model for EFL writing curriculum within the multiliteracies framework. The class was conducted 
in a student's-centered, real-world problem-solving and multiliteracies-enhancing manner. Four designing procedures were integrated into the instructional process: situated practice, overt instuction, critical framing and transformed practice. Students showed great interest and autonomy in participating in multimodal tasks. Their products based on multiliteracies demonstrated their abilities of group cooperation and their communicative competence in new digital literacies. Through designing activities, students experienced the shift of roles from passive receivers of multimedia information to active producers. Findings from the follow-up interview revealed that students generally held a positive attitude towards this new model of instruction. They reported that they were more actively involved in the learning process and became more responsible for their group task. Students' experiences of conveying meanings via multiple semiotic resources in authentic contexts will exert a positive influence on the enhancement of their multiliteracies competence and their abilities of analyzing digital information critically. The study provides useful insights into writing instruction for EFL learners in the era of new media communication. In the light of it, the implication for instructors is that they should not merely employ resources of multiple communication modalities as scaffolding in teaching, but they have to advance and innovate their pedagogical approaches from the perspective of multiliteracies to address learners' needs in the digitally-intensive, realworld interactions. Further studies may explore the assessment method of writing curriculum applying multiliteracies pedagogy to gain better perceptions.

\section{REFERENCES}

1. Cole, D. R., \& Pullen, D. L. (2010). Multiliteracies and the agency involved with computer operations in education. Multiliteracies in motion: Current theory and practice.

2. Anstey, M., \& Bull, G. (2006). Teaching and learning multiliteracies: Changing times, changing literacies. International Reading Association. 800 Barksdale Road, PO Box 8139, Newark, DE 19714-8139.
3. Li, Y., \& Feng, D. (2017). Power point design and construction of linguistic knowledge: from perspective of multiliteracy pedagogy. $e$-Education Research,5,95-100. (Audiovisual education research).

4. The New London Group. (1996). A pedagogy of multiliteracies: Designing social futures. Harvard educational review, 66(1), 60-93.

5. Kalantzis, M., \& Cope, B. (2005). Learning by Design Guide. Melbourne: Common Ground.

6. Khadka, S. (2018). A broad-based multiliteracies theory and praxis for a diverse writing classroom. Computers and Composition, 47, 93-110.

7. Dezheng, F. (2017). Classroom Teaching Design Based on the Multiliteracies Pedagogy: A Case Study of an English Linguistics Lesson [J]. Foreign Languages in China, 3, 55-63.

8. Delu, Z., \& Rui, L. (2014). Pedagogical Design on Developing Students' Multiliteracies in FL Learning_-A Case Study of Students' Classroom Oral Presentation [J]. Foreign Languages in China, 3, 45-52.

9. Rijlaarsdam, G., Braaksma, M., Couzijn, M., Janssen, T., Kieft, M., Raedts, M., ... \& Van den Bergh, H. (2009). The role of readers in writing development: Writing students bringing their texts to the test. The SAGE handbook of writing development, 436-452.

10. Wang, J. (2019, January). Research on Blended Teaching Mode of College English based on Rain Classroom. In 2018 6th International Education, Economics, Social Science, Arts, Sports and Management Engineering Conference (IEESASM 2018). Atlantis Press.

11. Halliday, M. A. K., \& Matthiessen, C. M. (2013). Halliday's introduction to functional grammar. Routledge.

12. Hafner, C. A., \& Miller, L. (2011). Fostering learner autonomy in English for science: A collaborative digital video project in a technological learning environment. Language Learning \& Technology, 15(3), 68-86.

13. Burn, A., \& Parker, D. (2003). Analysing media texts. London, UK: Continuum. 